\title{
PENCARIAN DANA MASJID DI JALAN RAYA DALAM PERSPEKTIF HUKUM ISLAM
}

\author{
Moch. Cholid Wardi \\ (Sekolah Tinggi Ilmu Tarbiyah Nahdhatut Thullab Sampang, Jl. Diponogoro \\ Sampang,email; cholide@yahoo.co.id.)
}

\begin{abstract}
abstrak
Artikel ini bertujuan untuk menggambarkan aktifitas pengorganisasian sumbangan di jalan raya dari perspektif hukum Islam. Kegiatan ini memunculkan kontradiksi, ada pihak yang mendukung dan ada pihak yang menolaknya. Mereka berdebat satu sama lain untuk mempertahankan pendapat mereka sendiri. Walhasil, perspektif hukum Islam memastikan apakah kegiatan tersebut yang legal atau tidak. Penegakan hukum Islam terhadap pendapat teresebut harus memandang beberapa alasan dasar, termasuk kondisi geografis, motif ekonomi sosial budaya maupun motof-motifvertikal tertentu. Selain itu, ia harus mengantisipasi dampaknya terhadap masyarakat Islam secara umum dan prioritas keuntungan ketimbang mafsadah-nya. Bahkan, permintaan sumbangan di jalan raya bisa mendatangkan madlarah, seperti perilaku mengemis yang dilarang dalam Islam, karena menurunkan martabat umat Muslim secara universal. Yang tidak kalah pentingnya, konsep bangunan masjid tidak dikategorikan dlarûrah.
\end{abstract}

\begin{abstract}
This article aims to describe the activity of street organizing donation (an activity of organizing a donation done on the street or highway) from Islamic law perspective. This activity arises a contradiction, there has been a side support it but another side that reject it. They argue to each other to defend their own opinion. As a result, an Islamic law perspective looks urgent to ensure whether that activity is legal. The Islamic law enforcement against the argue must regard some basic grounds including geographic, social-cultural, economic motives as well as certain vertical ones. Moreover, it has to anticipate its impact on Islamic society generally and the priority of advantages better than its mafsadah. In fact, street organizing donation could come up madlarah as it looks the act of begging that is forbidden
\end{abstract}


in Islam, universally decrease Muslims dignity. Last but not least, the concept of mosque building is not categorized dlarûrah.

\author{
Kata-kata Kunci \\ pembangunan masjid, hukum Islam, mashlahah, mafsadah, sadd \\ al-dzarî'ah
}

\title{
Pendahuluan
}

Syarî́ah adalah media dan katalisator yang digunakan untuk menyampaikan nilai-nilai kebenaran ilâhiyah. Ia juga dapat didefinisikan sebagai rancangan Tuhan untuk agama serta metode beramal bagi para mukmin dan para mujtahid dalam memberi fatwa. Hukum-hukum syarî'ah merupakan aplikasi substansi rancangan Tuhan dan penerapan metode rahmat dalam kehidupan manusia. Implementasi tersebut dapat berupa perintah langsung dari Allah seperti hukum-hukum ibâdah, sebagian muamalah dan hukuman. Kadangkala berupa ijtihâd dan penafsiran para ulamâ'. ${ }^{1}$ Kesemuanya itu berorientasi pada hakikat hukum Islam berupa maqâshid al-tasyrî́, ${ }^{2}$ yaitu untuk mewujudkan kebaikan sekaligus menghindarkan keburukan atau menarik manfaat dan menolak madlarah. Jadi inti dari konsep maqâshid al-syarî’ah adalah mashlahah. ${ }^{3}$

Islam adalah agama yang syâmil (menyeluruh/komprehensif) ${ }^{4}$ dan kâmil (sempurna), sehingga dalam hukum-hukumnya tertuang berbagai permasalahan yang berkenaan dengan manusia dalam hidup sebagai makhluk individu dan makhluk sosial. Islam sama

1 Lukman Hakim et al., Syariah Sosial; Menuju Revolusi Kultural (Malang: UMM Press, 2004), hlm. 75.

${ }^{2}$ Ahmad Kamaruzzaman Bustaman, Islam Historis; Dinamika Studi Islam di Indonesia (Yokyakarta: Galang Printika, 2002), hlm. 94.

${ }_{3}$ Kemaslahatan di sini dapat diartikan sebagai sesuatu yang mengandung kebaikan dan manfaat bagi manusia baik secara individu maupun kelompok dengan cara menghindari kerusakan baik sebelum atau sesudahnya atau mengikuti dan menyertainya. Konsep mashlahah ini dirumuskan oleh oleh al-Ghazâlî dan dipopulerkan oleh al-Syâthibi. Ia terdiri dari lima jenis pemeliharaan, yaitu pemeliharaan agama, jiwa, reproduksi, akal, dan harta benda. Lihat Ahmad alRaysuni, Ijtihad antara Teks, Realitas, dan Kemaslahatan Sosial (Jakarta: Erlangga, 2002), hlm. 19.

${ }^{4}$ Muhammad Alwi al-Maliki, Syariat Islam; Pergumulan Teks dan Realitas, (Yogyakarta: el-SAQ Press, 2003) 
sekali tidak menganut paham otoritarianisme yang cenderung mengatur dengan tanpa ada pengertian dan pemahaman, dengan kata lain Islam cenderung demokrat dan berorientasi pada rahmat li al-âlamîn. 5

Agama Islam ${ }^{6}$ adalah agama yang global dan universal7, sehingga salah satu kelebihannya adalah mengatur hubungan yang mempunyai 2 (dua) dimensi yang senantiasa harus dipelihara oleh umatnya, yaitu hubungan manusia dengan Tuhannya ( $\underline{h} a b l$ min Allâh) dan hubungan manusia dengan manusia lainnya (habl min al-nâs). Hubungan antara manusia dengan Tuhannya itu, kemudian disebut dengan ibâdah, dan hubungan manusia dengan sesamanya dinamakan muâ'malah.

Agama Islam selalu menganjurkan umatnya agar supaya dalam berinteraksi dengan sesamanya senantiasa berlomba-lomba berbuat kebajikan. Di samping itu, manusia diciptakan oleh Allah sebagai khalîfah di muka bumi ini dengan tujuan agar manusia selalu memelihara, mengelola, dan mengatur bumi ini, serta untuk

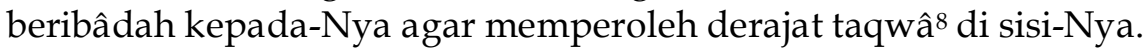

Dengan dasar pemikiran di atas, dapat dikatakan bahwa manusia hidup di bumi Allah tidak lain hanyalah semata-mata menjalankan perintah dan menjauhi semua larangan-Nya. Sebagai

5Yang dimaksud dengan rahmat li al-'alamîn adalah bahwa Muhammad diutus sebagai penutup para Nabî dengan membawa risalahnya dan risalah para nabî terdahulu sebagai rahmat bagi semua manusia tanpa terkecuali. Lihat Wahbah alZuhaylî, al-Tafsîr al-Munîr fî al-'Aqîdah wa al-Syarî'ah wa al-Manhaj, vol. 17 (Kairo: Dâr al-Kutub al-Mu'âshir, 1991), hlm. 146.

${ }^{6}$ Konsep Islam sebagai al-din, yang bersumber dari al-Qur'an meliputi pengaturan semua aspek kehidupan manusia, baik pengaturan hubungan manusia dengan Tuhannya, maupun pengaturan hubungan antar makhluk. Dîn al-Islam mencakup hukum tentang sistem keyakinan (ahkâm I'tiqâdiyah), hukum yang berhubungan dengan pengaturan ucapan, perbuatan dan hubungan antar manusia (ahkâm 'amaliyah) yang berhubungan dengan keutamaan, kesempurnaan dan keindahan bagi diri manusia (ahkâm khuluqiyah). Lihat Suparman Usman, Hukum Islam; Asas-asas dan Pengantar Studi Hukum Islam dalam Tata Hukum Indonesia (Jakarta: Gaya Media Pratama, 2001), hlm. 12.

7Quraish Shihab, Membumikan Al-Qur'an (Bandung: Mizan, 1994), hlm. 286.

8 Derajat ini biasanya dicapai melalui tiga fase aqidah dan tiga fase hakikat. Adapun fase aqidah meliputi: Islam, iman dan ihşân. Sedangkan fase hakikat meliputi: 'Ilm alyaqîn, ilmu 'ayn al-yaqin, 'ilm haqq al-yaqîn. Lihat Mahmud Muhammad Thaha, Arus Balik Syarî'ah (Yokyakarta: LKiS, 2003), hlm. 23. 
konsekuensinya, mereka harus senantiasa berbuat kebajikan yang dapat mendatangkan kemaslahatan dan meninggalkan kemungkaran yang dapat mendatangkan kemudharatan. Dalam konteks ini banyak umat Islam yang ingin melakukan kebajikan akan tetapi salah dalam mengaplikasikan keinginan tersebut. Dengan kata lain, banyak di antara kaum Muslim yang masih belum memahami secara sempurna hakikat Islam itu sendiri sehingga ia melakukan sesuatu dengan tujuan untuk memuliakan agama, tetapi justru sebaliknya, ia telah membuat agamanya terhina.

Terkait dengan problem pencarian dana untuk pembangunan masjid di jalan raya, ternyata dalam realitas masyarakat banyak terjadi proses "perangkulan terhadap agama" untuk melegitimasi kepentingan tertentu, baik dalam hal politik, ekonomi, maupun budaya. Hal lain yang dapat dilihat adalah pemakaian jargon agama untuk melegitimasi kegiatan sosial, yaitu suatu proses pengagamaan dalam rangka membentuk aktivitas sosial yang pada akhirnya dijadikan sebagai tradisi yang tidak ditinjau ulang. Kondisi ini memunculkan pertanyaan apakah perilaku tersebut benar-benar mendapat legitimasi agama?

Dari beberapa keterangan di atas, penulis ingin menyampaikan bahwa di tengah-tengah masyarakat terjadi kesalahpahaman dalam memandang agama sehingga muncul perilaku yang tidak sesuai dengan ajaran agama tetapi dilakukan dengan mengatasnamakan "agama". Fenomena ini dapat dilihat pada aktivitas pencarian dana untuk pembangunan masjid di jalan raya yang hingga saat ini masih marak dilakukan, terutama di daerah-daerah yang pemahaman keagamaan masyarakatnya cenderung konservatif, tekstual, dan skriptual.

Maraknya penggalangan dana untuk pembangunan fasilitas sosial keagamaan dewasa ini menimbulkan pemandangan yang memprihatinkan. "Proyek" penggalangan dana ini dilakukan di jalan -baik jalan nasional maupun propinsi- dengan cara membuat "marka drum dan manusia" yang sejatinya mengakibatkan kelancaran lalu lintas terganggu. Pertanyaan mendasar berkaitan dengan hal ini adalah apakah yang demikian itu dapat dibenarkan oleh Islam? Realitas ini perlu ditinjau dari berbagai sisi seperti sosiologis dan hukum Islam, sehingga apabila semua tinjauan sudah dilakukan, 
apakah nantinya kegiatan tersebut masih dapat dilegalkan baik dalam perspektif hukum positif maupun hukum Islam?

Problem pencarian dana di jalan raya memiliki beberapa sisi negatif yang harus dicermati, di antaranya adalah: Pertama, bahwa kegiatan pencarian dana di jalan raya tersebut dapat mengganggu perjalanan dan dapat menimbulkan kemudlaratan, baik bagi pengguna jalan maupun bagi pelaku-pencari amal itu sendiri. Hal ini dapat dikaji dengan mengacu pada Hadits yang menerangkan bahwa apabila ada halangan di jalan dan kita menghilangkannya, maka itu termasuk ke dalam kategori shadaqah. Dengan kata lain, menghilangkan sesuatu yang dapat mendatangkan penderitan bagi orang lain adalah perbuatan mulia yang diperintahkan oleh syara'. Sedangkan pada fenomena pencarian dana pembangunan masjid di jalan raya, justru telah "menghadirkan" penderitaan bagi orang lain. ${ }^{9}$

Kedua, meminta-minta baik dalam konteks kepentingan individu maupun untuk kepentingan sosial merupakan suatu tindakan yang kurang dan tidak sejalan dengan nafas Islam, karena Islam sendiri telah menegaskan bahwa "memberi" posisinya lebih baik dari pada "menerima". Oleh karenanya, Islam sebagai agama yang membawa kemaslahatan senantiasa manganjurkan kepada umat Muslim untuk mengeluarkan hartanya melalui zakat, infâq, shadaqah, wakaf, hibah dan sebagainya.

Ketiga, secara sosiologis dan psikologis, perlu dipertimbangkan bahwa tidak semua pengguna jalan berasal dari kalangan umat Muslim. Ketika realitasnya demikian, maka hal yang perlu direnungkan adalah implikasi dari kegiatan tersebut, yakni terganggu atau terhinanya martabat dan citra agama Islam karena telah dinodai oleh kegiatan "pencegatan" pengguna jalan dengan argumentasi untuk kepentingan Islam. Padahal dalam maqâshid al-tasyrî', memelihara agama adalah hal pertama yang harus dijadikan landasan dalam beragama.

Keempat, masalah yang juga signifikan untuk dikaji adalah prosentase yang diperoleh oleh para pencari amal dari hasil pencarian

\footnotetext{
${ }_{9}^{9}$ Dalam konteks ini berarti pencarian dana pembangunan masjid di jalan raya dapat mendatangkan kemudlaratan. Kasus nyata terjadi di Banyuwangi, di mana tiga orang pencari amal yang berdiri di tengah jalan meninggal dunia akibat tertabrak mobil. Periksa Ahmad Zahro, Tradisi Intelektual NU (Yogyakarta: LKIS, 2004), hlm. 190.
} 
dana pembangunan masjid tersebut. Apakah perolehan prosentase bagi para pencari amal tersebut dapat dibenarkan atau tidak oleh hukum Islam? Persoalannya menjadi dilematis. apabila mereka dibayar, apakah pembayarannya tersebut sah? Sebaliknya, apabila mereka tidak dibayar, bagaimana dengan waktu yang telah mereka luangkan dengan berdiri di tengah jalan sepanjang hari?

\section{Masjid dalam konsep Islam}

Masjid merupakan perangkat masyarakat yang pertama didirikan oleh Rasûlullâh ketika beliau sampai di Madinah setelah menempuh perjalanan hijrah yang melelahkan. Arsitektur bangunannya sangat sederhana dan jauh dari kesan mewah. Masjid tersebut dibangun pada suatu lokasi di sudut kota yang hanya ditandai batas-batasnya, beratapkan ranting dan dahan kering dan di sudutnya terdapat sebongkah pohon kurma sebagai tempat imam dan khathîb berdiri. Di tempat sedemikian sederhananya, Rasûlullâh menerima banyak ayat al-Qur`an yang kemudian dicatat, dihafal, dipahami, dan diamalkan di bawah bimbingan beliau. Di tempat itu pula Rasûlullâh bertemu dengan para sahabat, merundingkan langkah-langkah pembinaan umat mulai dari masalah agama, sampai pada persoalan kesejahteraan hidup bermasyarakat. ${ }^{10}$

Itulah fungsi masjid yang ideal sebagaimana yang dicontohkan Rasûlullâh. Ini memang sejalan dengan namanya, masjid yang berarti tempat bersujud atau berbakti kepada Allah, pusat kegiatan jemaah muslim dalam menata dan menatap masa depan hidupnya, baik yang berjangka pendek (dunia), maupun yang berjangka panjang (akhirat). Anjuran Rasûlullâh kepada umat Muslim agar banyak mendirikan masjid adalah agar difungsikan sebagai sentral kegiatan jamaah, yang akan menjabarkan tujuan risalah Muhammad, yakni rahmat li al'âlamîn, dan bukan masjid yang bertikar kumuh dan air yang sempat menghijau (berlumut), bahkan di dalam al-Qur`an ada sindiran yang pedas akan adanya masjid yang justru menceraiberaikan umat. ${ }^{11}$

10 Masjid merupakan tempat awal gerakan pendidikan dan penerangan Islam, pelaksanaan dab penegakan peradilan, dan bahkan tempat pembicaraann perjanjian dengan tetangga non muslim, lihat Aboe Bakar, Sedjarah Masjid (Banjarmasin: Toko Buku Adil, 1955), hlm. 5.

11 Zaini Dahlan, "Kata Pengantar", dalam Manajemen Masjid dalam Pembangunan Masyarakat; Optimalisasi Peran dan Fungsi Masjid, (Jakarta: Gaya Media Pratama, 1995) 
Kedudukan masjid dalam ajaran Islam sangat terhormat. Masjid merupakan simbol persatuan dan kesatuan umat Muslim. Masjid adalah milik umat Muslim dari kelas sosial mana pun. Semuanya mempunyai hak dan kewajiban yang sama untuk memasuki dan memakmurkannya dengan berbagai kegiatan ibâdah. Semuanya melakukan ruku' dan sujud menghadap kiblat sebagai pengakuan akan kebesaran Allah. ${ }^{12}$

Namun sangat disayangkan ketika ada sikap sebagian umat Muslim yang masih belum memfungsikan masjid sesuai dengan apa yang semestinya. Kondisi ini dapat dilihat dari pemahaman umat Muslim terhadap masjid sejak masa Nabi hingga sekarang. Ada dua kategori pemahaman umat Muslim terhadap fungsi masjid, yaitu:13 Pertama, memahami masjid sebagai tempat ibâdah (shalat) untuk mendekatkan diri kepada Allah, berzikir dan memohon ampunan dan sebagai pusat pembinaan Islam sebagaimana digambarkan dalam al-Qur`an dan dicontohkan oleh Nabi.

Kedua, memahami masjid hanya sebagai tempat melaksanakan ibâdah shalat saja. Pemahaman ini tidak sesuai dengan konsepsi Islam, karena masjid bukan hanya berfungsi sebagai tempat shalat. Pemahaman yang kedua ini masih mendominasi mayoritas pemahaman umat Muslim, sama halnya dengan pemahaman agamaagama lain terhadap tempat ibâdahnya, yaitu hanya sebagai tempat melaksanakan ibâdah ritual.

Membangun dan mendirikan masjid tampaknya dapat saja diselesaikan dalam tempo yang tidak terlalu lama. Namun ia akan menjadi sia-sia jika di atas masjid yang didirikan itu tidak terdapat aktivitas yang dapat memakmurkannya. Masjid tersebut menjadi tidak akan terawat, cepat rusak, tanpa jamaah dan sepi dari berbagai kegiatan yang bernafaskan keagamaan. Dengan memakmurkan masjid secara fisik, dimaksudkan bangunannya bagus, bersih, indah dan megah; sedangkan secara spiritual ditandai dengan antusiasme jamaah dalam menunaikan ibâdah dan kegiatan-kegiatan keagamaan lainnya.

Masjid yang makmur adalah masjid yang berhasil tumbuh menjadi sentral dinamika umat. Sehingga masjid benar-benar

12 Ibid., 39-40.

13 Ibid. 
berfungsi sebagai tempat ibâdah dan pusat kebudayaan Islam dalam arti luas. ${ }^{14}$ Memakmurkan masjid merupakan tugas dan tanggung jawab seluruh umat Muslim, sebagaimana firman Allah dalam surat al-Tawbah ayat 18 , yaitu:

إنما يعمر مساجد الله من آمن بالله واليوم الأخر واقام الصلاة واتى الزكاة ولم يخش إلا الله فعسى اولئك أن يكونوا

"Hanyalah yang memakmurkan masjid-masjid Allah ialah orangorang yang beriman kepada Allah dan hari kemudian, serta tetap mendirikan shalat, menunaikan zakat dan tidak takut (kepada siapapun) selain kepada Allah, maka merekalah orang-orang yang diharapkan termasuk golongan orang-orang yang mendapat petunjuk".15

\section{Fenomena Pencarian Dana untuk Pembangunan Masjid di Jalan Raya}

Sedikitnya ada empat hal yang memotivasi umat Muslim untuk melakukan pencarian dana di jalan raya, yaitu letak geografis, sosial budaya, ekonomi, dan motivasi yang bersifat vertikal.

1. Geografis

Letak geografis suatu daerah mempunyai pengaruh terhadap kebutuhan masyarakatnya. Dalam hal ini masjid yang merupakan tempat ibâdah bagi mayoritas umat Muslim menjadi sebuah kebutuhan agar supaya mereka mendapat kemudahan dalam beribâdah. Oleh kerenanya, masjid yang banyak merupakan sebuah kebutuhan yang harus dipenuhi pada realitas masyarakat yang memiliki letak geografis yang tidak strategis. Sebagai sebuah sampel, di Pamekasan terdapat sekitar 1016 masjid dan 5079 mushallâ. 16 Ini tentu saja merupakan jumlah yang cukup fantastis ketika melihat luas daerahnya yang hanya sekitar $792 \mathrm{KM}^{2}$ dengan jumlah penduduk 196.958 jiwa. Namun

14 Moh. E. Ayub, et al., Manajemen Masjid, (Jakarta: Gaya Media Pratama, 2001), hlm. 72.

${ }^{15}$ Compact Disk Holy Qur'an V. 6.50 (Beirut: Sakhr Dâr al-'âlamiyah)

16 Bapedda Kabupaten Pamekasan, Kabupaten Pamekasan dalam Rangka Pamekasan Regency in Figures (Pemda Pamekasan, 2005), hlm. 87. 
demikian, banyaknya jumlah masjid tersebut bisa dipahami mengingat daerah di mana antara satu komunitas penduduk dengan penduduk lainnya berjauhan sehingga penduduk yang lokasinya berjauhan dengan masjid menjadi kesulitan untuk melakukan ibâdah. Oleh karenanya, masjid dibangun untuk memenuhi kebutuhan tersebut.

Ketika masjid menjadi sebuah kebutuhan yang harus terealisasi dan terbentur dengan minimnya pendanaan, maka ide untuk menggalang dana di jalan menjadi sebuah alternatif. Oleh karenanya, masyarakat yang tidak memiliki manajemen yang profesional dalam pengelolaan dananya akan cenderung melakukan sesuatu yang dianggap efektif dan efisien tanpa harus melihat konsekuensinya baik secara hukum maupun sosial budaya.

2. Sosial budaya

Dalam konsep sosial keagamaan, masyarakat senantiasa ingin mengekspresikan dirinya sebagai umat Muslim yang baik, dengan cara melakukan pengembangan di bidang keagamaan. Salah satunya adalah membangun sebuah masjid dengan arsitektur yang indah. Akan tetapi mereka keliru ketika ingin memakmurkan masjid dengan cara membangun masjid yang bagus di daerahnya. Mereka tidak berpikir bahwa sebenarnya untuk memakmurkan masjid, yang sangat dibutuhkan adalah spirit kemasjidannya sehingga yang harus dilakukan adalah memberdayakan masjid secara maksimal.

Kondisi ini menyebabkan mereka memiliki kecenderungan berlomba-lomba untuk membangun dan merenovasi masjid. Konsekuensinya, mereka akan mengalami kendala dalam hal pendanaan. Berbagai cara dilakukan untuk merealisasikan pembangunan dan renovasi masjid. Salah satunya adalah dengan menggalang dana di jalan raya.

2. Ekonomi

Masalah ekonomi merupakan komponen vital yang menyebabkan munculnya kegiatan pencarian dana di jalan raya. Problem pendanaan yang dialami masyarakat tidak terlepas dari perilaku mayoritas mereka yang menginginkan didirikannya sebuah masjid yang bagus. Ambisi untuk mendirikan masjid yang megah tanpa melihat alokasi dana yang tersedia menjadikan 
masyarakat melakukan 'manuver' melalui penggalangan dana dengan cepat tanpa harus mengeluarkan biaya operasional yang besar dan pemikiran yang berat, yaitu mencari dana di jalan raya. Mereka menjadikan jalan sebagai "aset" dalam mencari dana untuk pembangunan masjid. Mencari dana di jalan raya merupakan alternatif yang dilakukan masyarakat karena mereka menganggap tidak ada cara lain yang lebih efektif dan efisien untuk dilakukan. Padahal dalam realitas kehidupan modern seperti saat ini masih banyak strategi yang lebih profesional dan Islami yang dapat dilakukan untuk menggalang dana.

3. Motivasi vertikal yang berimplikasi terhadap munculnya aktivitas sosial yang mengatasnamakan agama

Tradisi keagamaan yang bersifat dogmatis harus dikritisi kembali agar muncul wacana baru yang lebih Islami dan rasional. Hal itu dikarenakan, Islam, pada dasarnya, merupakan agama yang syâmil (menyeluruh, komprehensif) ${ }^{17}$ dan kâmil (sempurna), sehingga dalam hukum-hukumnya tertuang berbagai permasalahan yang berkenaan dengan kebutuhan seorang hamba dalam menjalani kehidupan, baik sebagai makhluk individu dan makhluk sosial. Apabila tradisi keagamaan ini tidak dianalisis dan ditinjau ulang, maka akan terjadi distorsi pemikiran yang pada akhirnya muncul kesalahpahaman dalam menafsirkan agama. Sebagai konsekuensinya, obyektivitas pemikiran keagamaan menjadi semakin jauh karena telah bercampur dengan kepentingan pribadi suatu golongan, bahkan kepentingan politik.

Menerapkan dan mengembangkan pola kehidupan keagamaan yang aktual18 berdasarkan al-Qur'an dan al-Hadits harus dilakukan agar tidak muncul kegiatan sosial yang mengatasnamakan agama. Artinya, ketika umat Muslim senantiasa berpedoman pada al-Qur`an dan al-Hadits dengan interpretasi yang komprehensip, maka tidak akan muncul kegiatan-kegiatan yang tidak Islami seperti proses pencarian dana

17 Al-Maliki, Syariat Islam, hlm. vii.

18 Pola kehidupan keagaman yang aktual di sini merupakan pola keagamaan yang menghidup-suburkan keimanan dan ketaqwaan, juga harus melahirkan kegairahan untuk mendayagunakan dan meningkatkan kemampuannya dengan seoptimal mungkin. Lihat M. Nasir Tamara dan Elza Peldi Taher, Agama dan Dialog antar Peradaban (Jakarta: Paramadina, 1996), hlm. 177. 
pembangunan masjid di jalan raya. Jadi kesalahan dalam mengartikan kegiatan keagamaan pada realitas pelaku-pencari dana yang beranggapan bahwa mereka melakukannya "untuk agama" dengan harapan mendapat pahala dari Allah perlu untuk ditinjau ulang, apakah kegiatan itu benar-benar Islami ataukah hanya dibungkus dengan kain Islam saja.

Untuk mengaktualisasikan ajaran agama yang benar dan konsekuen, perlu dipaparkan beberapa permasalahan keagamaan terkait dengan proses pencarian dana di jalan raya, di antaranya adalah: Pertama, bahwa proses pencarian dana untuk pembangunan masjid di jalan raya merupakan proses pengagamaan sebuah aktivitas sosial karena tidak ada ayat alQur`an, al-Hadits, kaidah ushûliyah maupun kaidah fighiyah yang dapat dijadikan sebagai sandaran hukum untuk melegalkan kegiatan mereka, terutama ketika dibenturkan dengan konsep mashlahah. Para pelaku-pencari dana di jalan raya termakan oleh doktrin yang mengatakan bahwa apabila seseorang melakukan kebaikan untuk kegiatan sosial keagaman, maka ia akan mendapatkan balasan yang setimpal dengan apa yang telah dilakukannya. Anggapan ini melahirkan aktivitas yang dilakukan dengan berdasar pada agama yang sebenarnya memiliki distorsi pemahaman dari yang semestinya. Oleh karenanya, dapat dikatakan bahwa kegitan pencarian dana untuk pembangunan masjid di jalan raya ini terkesan dicarikan hukum kebolehannya sehingga format hukumnya tidak orisinil dan cenderung ditarik pada sebuah kepentingan.

Kedua, keefektifan mencari dana di jalan raya antara lain adalah lokasi pencarian yang terbuka. Aspek ini memberikan beberapa dampak, di antaranya adalah memberikan kesempatan kepada penyumbang untuk tidak terlalu sulit dalam mentransfer harta bendanya untuk kepentingan Islam, strategis dalam rangka mencari peluang yang bersifat temporal seperti "pasaran", dan yang terakhir adalah munculnya gairah menyumbang bagi orangorang yang memiliki kepentingan tertentu. Misalnya seseorang yang ingin dikatakan dermawan dan mendapat pujian dari orang lain akan menyumbang secara terang-terangan.

Jadi sebenarnya, di samping ada maksud mulia dalam sebuah aktivitas sosial pencarian dana di jalan raya, terdapat 
maksud-maksud lain yang pada akhirnya menimbulkan perilakuperilaku yang tidak Islami. Walaupun sisi negatif dari proses pencarian dana ini tidak dimaksudkan sebagai tujuan awal, akan tetapi bagaimana pun dampak yang ditimbulkan harus diperhitungkan untuk merumuskan hukum yang sebenarnya.

\section{Pencarian Dana di Jalan Raya dalam Perspektif Hukum Islam}

1. Tinjauan al-Qur`an dan al-Hadits

Dalam tinjauan al-Qur'an dan al-Hadits, terdapat beberapa hal yang perlu dilihat. Pertama, secara spesifik, al-Qur'an tidak pernah memerintahkan umat Muslim untuk membangun masjid kecuali hanya kepada pemerintah. Al-Qur'an hanya memerintahkan kepada umat Muslim untuk memakmurkan masjid. Hal ini mengindikasikan bahwa membangun masjid yang banyak itu tidak dianjurkan oleh Islam, tetapi memakmurkan masjid yang ada adalah kewajiban bagi seluruh umat Muslim.

Di antara ayat al-Qur`an yang memerintahkan untuk memakmurkan masjid adalah surat al-Tawbah (10):17-18.

$$
\begin{aligned}
& \text { ما كان للمشركين أن يعمروا مساجد الله شاهدين على أنفسهم بالكفر أولئك حبطت أعمالهم وفي النار هم }
\end{aligned}
$$

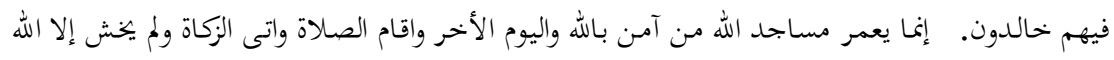

$$
\begin{aligned}
& \text { فعسى اولئك أن يكونوا من المهتدين }
\end{aligned}
$$

"Tidaklah pantas orang-orang musyrik itu memakmurkan masjidmasjid Allah, sedang mereka mengakui bahwa mereka sendiri kafir. Itulah orang-orang yang sia-sia pekerjaannya, dan mereka kekal di dalam neraka. Hanyalah yang memakmurkan masjid-masjid Allah ialah orangorang yang beriman kepada Allah dan hari kemudian, serta tetap mendirikan shalat, menunaikan zakat dan tidak takut (kepada siapapun) selain kepada Allah, maka merekalah orang-orang yang diharapkan termasuk golongan orang-orang yang mendapat petunjuk"..19

Perintah untuk membangun masjid hanya terdapat di dalam Hadits, seperti:

${ }^{19}$ Compact Disk Holy Qur'an V. 6.50 (Beirut: Sakhr Dâr al-'Alamiyah) 


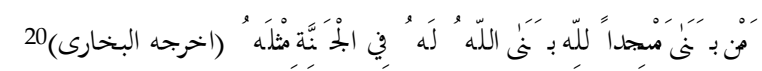

"Barang siapa yang membangun masjid, maka Allah akan membangunkan rumah di surga"

Kendati pun Islam memerintahkan umatnya untuk membangun masjid melalui Hadits Nabi di atas, namun perintah untuk memakmurkannya lebih banyak dan lebih kuat. Hal ini menunjukkan bahwa memakmurkan masjid lebih penting atau lebih diperintahkan daripada mambangun masjid secara fisik. Memakmurkan masjid dalam konteks ini adalah melakukan berbagai kegiatan ibâdah dan kegiatan lain, seperti menyelenggarakan aktivitas intelektual, sosial, kebudayaan dan lain sebagainya di masjid. Tujuannya, agar masjid memiliki eksistensi yang memberikan makna bagi kehidupan umat Muslim. ${ }^{21}$ Kalaupun Hadits tersebut dijadikan sebagai dasar pembangunan masjid, bagaimana status hukumnya ketika dilakukan dengan cara-cara yang tidak Islami. Sebagai sebuah ilustrasi, ketika ada seseorang yang tidak memiliki harta dan dia ingin melakukan shadaqah, kemudian sebagai solusinya dia melakukan pencurian dan hasilnya dishadaqahkan (melakukan kemungkaran untuk sebuah kebajikan), maka dapat dipastikan bahwa amalnya tersebut tidak sah.

Kedua, masalah lain yang harus dilihat adalah unsur mengganggu jalan yang pada akhirnya dapat menimbulkan kemudharatan. Dalam hal ini, Islam melarang umatnya untuk melakukan sesuatu yang dapat menggangu jalan. Salah satu Hadits yang menerangkan tentang hal itu adalah:

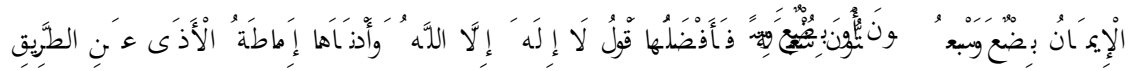

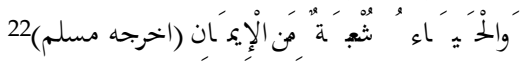

20 Muhammad Fu'âd Abd al-Bâqi, al-Lu'lu' wa al-Marjân, vol I (Beirut: Maktabah al'Ilmiyah, t.t.), hlm. 107.

${ }^{21}$ Syahidin, Pemberdayaan Umat Berbasis Masjid (Bandung: Alfabeta, 2007), hlm. 16.

22 Muhammad ibn Yûsuf al-Sanusî al-Hasanî, Mukammal Ikmâl al-Ikmâl bi Syarkh

Shahîh Muslim, vol. I (Beirut: Dâr al-Kutub al-Ilmiyah, 1996), hlm. 216. 
"Iman itu mempunyai tujuh puluh cabang atau enam puluh cabang, adapun yang paling utama adalah membaca lâ ilâha illâ Allah dan yang paling rendah adalah menghilangkan penderitaan dari jalan dan malu merupakan salah satu dari cabang iman".

Ketiga, problematika pencarian dana untuk pembangunan masjid di jalan raya yang memiliki keterkaitan secara langsung dengan nash al-Hadits adalah metode meminta-minta yang dilakukan dengan cara tidak terhormat. Padahal, cara yang lebih terhormat bahkan professional masih banyak. Akan tetapi karena lemahnya manajemen kemasjidan, maka kendala keuangan juga menjadi sebuah permasalahan. Rasûlullâh saw. bersabda:

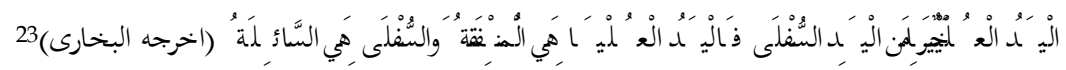

Artinya: "Tangan yang di atas lebih baik dari tangan yang di bawah, tangan yang di atas adalah memberi dan tangan yang di bawah adalah meminta-minta".

Kuat dan lemahnya iman seseorang dalam Hadits di atas dapat tercermin dari perilakunya sehari-hari. Salah satu indikasinya adalah putus asa dan kurang berusaha untuk mencapai sesuatu yang diinginkan. Kekuatan dalam Hadits di atas tidak hanya dapat dipahami dengan iman, akan tetapi juga mengarah pada segala hal seperti ekonomi dan lain sebagainya. Oleh karenanya, sebagai umat Muslim yang baik, seharusnya tidak melakukan hal-hal yang dapat mendatangkan klaim kelemahan karena implikasinya sampai pada eksistensi agama Islam sendiri.

Pada realitas masyarakat pelaku-pencari dana untuk pembangunan masjid di jalan raya, kegiatan penggalangan dana yang dilakukannya mencerminkan perilaku meminta-minta yang mempunyai dampak ekspresi kelemahan umat Muslim. Oleh karenanya, kegiatan itu harus benar-benar diperhatikan dan dikritisi supaya tidak bertolak belakang dengan konsep Islam yang sebenarnya.

23 Al-Bâqî, al-Lu'lu', , hlm. 217. 
Keempat, Islam menyeru umatnya untuk senantiasa menjadi umat yang terbaik, baik dalam ibâdah maupun dalam perilaku sosial. Dalam konteks ini, pencarian dana untuk pembangunan masjid di jalan raya diakui atau tidak secara sosiologis maupun psikologis, telah mencemarkan nama baik umat Muslim secara keseluruhan. Hal ini dikarenakan tidak semua pengguna jalan adalah umat Muslim. Komunitas non muslim pun juga menggunakan jalan raya sebagai sarana transportasinya. Padahal Islam menyeru kepada ummatnya untuk menjadi umat terbaik. Dalam surat Ali Imrân (3): 110, Allah swt berfirman:

خنتم خير أمة أخرجت للناس تأمرون بالمعروف وتنهون عن المنكر وتؤمنون بالله ولو أمن أهل الكتاب لكان

Artinya: "Kamu adalah umat yang terbaik yang dilahirkan untuk manusia, menyuruh kepada yang ma`ruf, dan mencegah dari yang munkar, dan beriman kepada Allah. Sekiranya Ahli Kitab beriman, tentulah itu lebih baik bagi mereka; di antara mereka ada yang beriman, dan kebanyakan mereka adalah orang-orang yang fasik". (Q.S. Ali Imron: 110$)^{24}$

2. Tinjauan ushûl al-figh, qấ'idah al-fiqhiyah dan aqwâl al-fuqahâ'

Dalam tinjauan ushûl al-fiqh, qấ'idah al-fighiyah dan aqwâl alfuqahâ', sedikitnya ada lima hal yang harus diperhatikan dalam proses pencarian dana untuk pembangunan masjid di jalan raya, yaitu: (1) kegiatan tersebut mengandung unsur madlârah, (2) Pelaksanaannya cenderung mengarah pada aktivitas memintaminta, (3) Kegiatannya dapat merendahkan martabat umat Muslim secara umum, (4) Adanya prosentase yang diambil dari hasil pencarian dana, dan (5) Proses pembangunan yang dilakukan tidak termasuk dalam kategori dlarûrah.

a. Kegiatan pencarian dana di jalan raya mengandung unsur madlârah

Menurut al-Syâtibi, sebagaimana dikutip oleh Permono, kemaslahatan itu dikembalikan pada pemeliharaan

${ }^{24}$ Compact Disk Holy Qur'ân V. 6.50 (Beirut: Sakhr Dâr al-'Âlamiyah), Q.S. Âli Imron: 110. 
pokok-pokok yang lima (al-muhâfazhah 'alâ al-kulliyât al-khams), yaitu: hifzh al-dîn (memelihara agama), hifzh al-nafs (memelihara jiwa), hifzh al-nasl (memelihara keturunan), hifzh al-aql (memelihara akal), dan hifzh al-mâl (memelihara harta). ${ }^{25}$ Kemaslahatan merupakan tujuan atau cita-cita hukum Islam (maqâshid al-ahkâm al-syar'îyah). Karenanya, ia harus benarbenar ditegakkan agar supaya Islam dapat mempresentasikan dirinya sebagai agama universal.

Pada realitas kegiatan pencarian dana di jalan raya, bahaya yang selalu menjadi taruhannya adalah nyawa. Hal ini dikarenakan para pencari dana melakukan aktivitasnya di tengah jalan dengan ekspresi yang variatif, mulai dari melambaikan tangan sampai dengan memperlambat laju kendaraan dengan sengaja. Kondisi ini sangat membahayakan jiwa para pelaku pencari dana sehingga harus dijadikan sebagai hal penting dalam perumusuan hukumnya. Di samping itu, ada juga yang sampai pada tahap pembuatan jalan secara zig-zag, nota bene sangat mengganggu para pengguna jalan. Padahal dalam Hadits Nabi sangat jelas disampaikan bahwa:

$$
\text { ل الا ضرر ولا ضرار }
$$

Artinya: "Tidak boleh mendatangkan kemudlaratan bagi diri sendiri dan orang lain". 26

Hadits ini merupakan cikal bakal lahirnya kaidah:

Artinya: "Kemudlaratan itu harus dihilangkan"

$$
\text { الضرر يزال }
$$

Kemudian kaidah lain yang lahir dari kaidah ini dan sesuai dengan masalah bahayanya aktivitas pencarian dana di jalan raya adalah:

25 Sjechul Hadi Permono, Dinamisasi Hukum Islam dalam Menjawab Tantangan Era Globalisasi (Surabaya: Demak Press, 2002), hlm. 13.

${ }^{26}$ Abû Faidl Muhammad Yâsin bin 'Isâ al Fâdanî, al-Fawâiid al-Jannîyah, vol. I (Beirut: Dâr al-Fikr, 1997), hlm. 246 
Artinya: "Kemudlaratan itu harus dihilangkan sedapat mungkin"

Kaidah figh di atas jelas sekali menunjukkan bahwa kemudharatan itu harus dihilangkan. Tetapi, sebaliknya, masyarakat yang melakukan aktivitas pencarian dana di jalan raya justru menghadirkan kemudlaratan, baik bagi diri sendiri maupun bagi orang lain. Kemudian pada wilayah ushûl figh, aktivitas pencarian dana di jalan raya itu dapat dikaitkan dengan konsep sadd al-dzarîah. ${ }^{27}$ Konsep ini berarti bahwa meskipun syara' tidak menetapkan secara jelas mengenai hukum sesuatu perbuatan, namun karena perbuatan itu ditetapkan sebagai washilah (perantara) bagi perbuatan yang dilarang, maka hukum perbuatan yang menjadi washilah ini dihukumi sebagaimana ditetapkannya hukum syara' terhadap hal yang pokok. Dengan kata lain, ketika tindakan membahayakan diri sendiri dan orang lain itu dilarang, maka kegiatan itu menjadi tidak diperbolehkan dengan alasan $l i$ sadd al-dzarî'ah. Demikian halnya dengan pencarian dana di jalan raya yang hukum asalnya adalah mubah akan menjadi haram ketika aktivitas tersebut mengandung unsur yang dapat membahayakan jiwa.

Kemudian, apabila kegiatan tersebut dikaitkan dengan perbuatan yang dapat mengganggu jalan, maka kaidah yang dapat dijadikan dasar adalah:

$$
\text { الإضطرار لا يبطل حق الغير }
$$

Artinya: "Keterpaksaan itu tidak dapat membatalkan hak orang lain"

27 Yang dimaksud dengan sadd al-dzarî́ah adalah menutupi jalan yang membawa kepada sesuatu, secara hissî atau ma'nawî̀, baik atau buruk. Lihat: Muhammad Abû Zahrah, Ushûl al-Figh (Beirut: Dâr al-Fikr, 1958), hlm. 290. Ibn al-Qayyim mengatakan bahwa secara lughawî, al-dzarî'ah ini mengandung konotasi makna yang netral tanpa memberikan penilaian terhadap hasil perbuatan. Oleh karenanya, ia mendefinisikannya dengan apa-apa yang menjadi perantara dan jalan kepada sesuatu. Periksa Amir Syarifuddin, Ushul Figh 2 (Jakarta: Logos Wacana Ilmu, 2001), hlm. 399 
Kaidah di atas menjelaskan bahwa suatu keterpaksaan yang menimpa diri seseorang tidak dapat menjadi sebuah alasan dihapusnya dosa dan menjadi sebab dimaafkan dari sesuatu hukuman atas pelanggaran hak orang lain. Dengan kata lain, jalan yang merupakan hak orang tanpa mengenal batas (agama, suku dan lain-lain), apabila diganggu baik untuk kepentingan diri sendiri atau untuk kepentingan sosial, tidak dapat dibenarkan. Hal ini dikarenakan mengorbankan hak orang lain tidak diperbolehkan dalam Islam.

b. Aktivitas meminta-minta yang tidak diperbolehkan dalam Islam

Sebagaimana telah diterangkan sebelumnya bahwa kegiatan meminta-minta dilarang Islam. Walaupun kadarnya tidak sampai pada tahap keharaman, namun ketika dilakukan secara terus-menerus dan memiliki dampak yang tidak baik, maka pekerjaan ini menjadi dilarang. Misalnya, ketika meminta-minta tersebut mendatangkan kemudlaratan, sebagaimana penjelasan tentang pelanggaran hifzh al-dîn dan hifzh nafs di atas, maka melakukan pencarian dana di jalan menjadi tidak diperbolehkan. Hal ini sesuai dengan kaidah:

$$
\text { اذا اجتمع الحلال والحرام غلب الحرام }
$$

Artinya: "Apabila berkumpul antara yang halal dan yang haram, maka yang dimenangkan adalah yang haram" .28

Dengan kaidah tersebut di atas dapat dipahami bahwa ketika meminta-minta diperbolehkan, maka perbuatan itu menjadi haram karena berkumpul dengan sesuatu yang haram, yaitu perbuatan yang dapat mendatangkan kemudlaratan dan menghadirkan penderitaan bagi orang lain. Dengan kata lain, ketika terdapat pertentangan antara mashlahah dan mafsadah, maka kemaslahatan menjadi prioritas utama. Menurut Ibn 'Ashûr, sesungguhnya syarî'ah itu hanya

${ }_{28}$ Abdul Mujib, Kaidah-kaidah Ilmu Figh; al-Qawaid al-Fiqhiyyah (Jakarta: Kalam Mulia, 2001), hlm. 51. Lihat juga: Abd al-Hamid Hakim, al-Sullam (Jakarta: Sa'adah Putra, t.t.), hlm. 64 . 
menuntut kemaslahatan alam, ${ }^{29}$ sehingga apa pun yang terjadi, manusia harus mengutamakan kemaslahatan. ${ }^{30}$

c. Kegiatan yang dapat merendahkan martabat Islam

Diakui atau tidak, kegiatan penggalangan dana di jalan raya dapat memunculkan image yang merendahkan Islam. Hal ini berimplikasi buruk pada eksistensi Islam sebagai agama yang syâmil dan kâmil serta berorientasi pada rahmat li al'âlamîn. Oleh karenanya, untuk mengaplikasikan visi dan misi Islam secara ideal, umat Muslim tidak boleh melakukan halhal yang dapat menjatuhkan nama baik Islam itu sendiri.

Aktivitas pencarian dana masjid di jalan raya mengakibatkan munculnya opini yang merendahkan 'martabat' agama Islam, tidak sesuai dengan konsep hifzh aldîn yang merupakan salah satu dari pokok-pokok maqâshid altasyrî́ yang harus dipelihara. Dalam perspektif al-Syâthibî, 31 memelihara agama dalam konteks apa pun adalah prioritas utama yang harus dilakukan oleh umat Muslim. Ia merupakan hal pokok yang paling vital karena menyangkut agama yang arahnya pada perihal yang bersifat vertikal-transendental.

${ }^{29}$ Muhammad Thâhir Ibn 'Âshûr, Maqûshid al-Sharî'ah al-Islâmiyah (Yordania: Dâr alNafâis, 2001), hlm. 299.

30 Bahkan menurut al-Thûfî, secara bahasa mashlahah adalah pengunaan sesuatu secara proporsional, seperti bolpoin yang digunakan untuk menulis, pedang untuk membacok dan lain sebagainya. Sedangkan mashlahah secara 'urf adalah sebab yang mendatangkan kebaikan atau manfaat, seperti perdagangan mendatangkan laba. Kemudian mashlahah secara shara' adalah sebab yang dapat menghantarkan pada maksud Syâri', baik ibâdah maupun adat. Lebih lanjut ia mengungkapkan bahwa mashlahah tersebut ada dua, yaitu mashlahah yang dimaksud Syâri' sebagai haknya, seperti ibâdah, dan mashlahah yang dimasksudkan oleh Syâri' untuk kemanfaatan makhlukNya. Kemudian dalam konsep maslahahnya juga, al-Thufî mengemukakan beberapa konsep yang bertentangan dengan konsep al-Ghazâlî, misalnya: 1) Kebebasan akal manusia untuk menentukan kemashlahatan dan kemudaratan dalam masalah mu'âmalah dan duniawi (adat), 2) Mashlahah adalah dalil syar'î yang berdiri sendiri dalam menetapkan suatu hukum, 3) Mashlahah hanya berlaku dalam ruang lingkup $m u^{\prime}$ âmalah dan adat, 4) Mashlahah merupakan dalil syara' yang paling kuat. Periksa Periksa Najm al-Dîn al-Thûfî, al-Ta'yîn fí Sharh al-Arba' în (Beirut: Mu'assasah al-Rayyan, 1998), hlm. 239 dan 272. lihat juga Amir Syarifuddin, Ushul Figh 2 (Jakarta: Logos Wacana Ilmu, 2001), hlm. 325; dan Ramadlan Abd al-Wadûd al-Lakhmî, alTa'lîl bi al-Mashlahah 'Ind al-Ushulîyin (Kairo: Dâr al-Huda, 1987).

31 Sjechul Hadi Permono, Dinamisasi Hukum Islam dalam Menjawab Tantangan Era Globalisasi, 13. 
Ketika pencarian dana untuk pembangunan masjid dikategorikan sebagai sebuah perilaku yang dapat mendatangkan kemudlaratan dalam tataran merendahkan martabat Islam secara umum, maka kegiatan tersebut tidak boleh dilakukan karena bertentangan dengan pokok-pokok yang harus dipelihara dalam syarî'ah.

d. Ketidakjelasan prosentase

Realitas di lapangan yang menunjukkan adanya indikasi pengambilan prosentase pada hasil penggalangan dana yang diperoleh -walaupun terjadi pada sebagian pelaku pencari dana- dan mencapai angka fantastis, yaitu antara $10 \%$ sampai dengan 25\% menjadi sebuah masalah. Hal ini dikarenakan harta yang diambil dari prosentase yang tidak layak itu mengakibatkan berkurangnya pemasukan pada masjid. Misalnya, sebuah masjid yang memiliki penghasilan rata-rata $\mathrm{Rp} 250.000 /$ hari, apabila dikurangi $25 \%$, maka dana yang masuk ke masjid hanya sebesar Rp 188.000/hari. Padahal dalam konsep Islam, harta yang didapat dari amal jariyah orang tidak dapat diambil secara sepihak kecuali dalam konsep wakaf produktif. Berkaitan dengan konsep ini, Abû Hanîfah membolehkan mengambil $10 \%$ sebagai imbalan karena mereka telah mengelola harta wakaf. ${ }^{32}$

e. Pembangunannya bukan dalam kondisi dlarûrah

Mayoritas pembangunan masjid yang menggunakan fasilitas jalan sebagai aset pencarian dana masih masuk pada tahap yang tidak begitu dibutuhkan. Artinya, pembangunan yang ada pada umumnya tidak memunculkan masalah yang signifikan dalam perspektif agama apabila tidak dilakukan. Hal ini berangkat dari kondisi masjid yang dibongkar atau direnovasi masih termasuk ke dalam kategori layak pakai. Tetapi masyarakat ingin memperindah atau memperbesar

32 Kebolehan mengambil 10\% dari harta wakaf produktif ini tidak dilakukan pada harta pokok, akan tetapi pada hasil dari pengelolaannya sehingga harta pokoknya tetap tidak berkurang. Lihat Mundhir Qahaf, Manajemen Wakaf Produktif, terj. Muhyidin Mas Rida (Jakarta: Pustaka al-Kautsar Grup, 2005), hlm. 199-200. Lihat juga Departemen Agama, Pedoman Pengelolaan dan Pengembangan Wakaf, (Jakarta: Dirjen Bimbingan Masyarakat Islam dan Penyelenggaraan Haji, 2003), hlm. 108-109 
masjid tersebut, sehingga membutuhkan dana yang besar dan, seterusnya, mengalami kendala ketika dana itu tidak terkumpul dengan cara-cara yang "Islami" dan "terhormat".

Dari keterangan tersebut dapat dikatakan bahwa andaikan alasan pelegalan pencarian dana di jalan karena dlarûrah, maka argumentasi tersebut dapat dipatahkan karena pada tataran empirisnya tidak demikian. Oleh karenanya, apabila proses pembangunannya sudah mencapai pada tahap dlarûrah, maka dengan cara apa pun dapat diperbolehkan dengan berpegangan pada kaidah figh yang berbunyi:

Artinya: "Kemudlaratan itu dapat membolehkan hal-hal yang
dilarang"

Kemudian kaidah lain yang terkait adalah:

$$
\text { اذا تعارض مفسدتان روعى اعظمهما ضررا بارتكاب اخفهما }
$$

Artinya: "Apabila ada dua mafsadah yang bertentangan, maka perhatikan mana yang lebih besar madlaratnya dengan dikerjakan yang lebih ringan kepada mudlaratnya".

Dari semua paparan di atas jelas bahwa perilaku mencari dana di jalan raya tidak dapat dibenarkan, sehingga diperlukan solusi-solusi yang lebih efektif guna pengembangan keagamaan ke depan. Sebagai salah satu solusi yang dapat dipertimbangkan adalah:

Pertama, membenahi manajemen pengumpulan dana untuk pembangunan masjid. Secara normatif sudah jelas bahwa agama Islam sangat menganjurkan untuk melaksanakan perintah yang disepakati sebagai kewajiban seperti zakat, maupun anjuran yang bersifat sunnah seperti infâq, shadaqah, hibah, waqaf dan lain sebagainya. Dalam hal ini, pihak-pihak yang memiliki kewenangan dan pengaruh di masyarakat seharusnya membangun kesadaran masyarakat Muslim untuk melakukan perintah agama tersebut. Pihak-pihak itu harus memberikan dorongan kepada setiap umat Muslim di wilayahnya untuk melakukan zakat, infâq, shadaqah dan wakaf, kemudian mengelolanya dengan sebuah manajemen yang profesional. Tampaknya, penanganan ini harus melibatkan peran 
pemerintah secara langsung atau diwakili oleh Departemen Agama selaku aparat yang mewilayahi bidang keagamaan. Memang pada tataran aplikasinya, format ini sulit dilaksanakan karena terbentur dengan berbagai sistem, akan tetapi kemungkinannya untuk terealisasi sangat besar.

Kedua, apabila langkah pertama yang merupakan solusi yang sangat efektif itu tidak dapat dilaksanakan dengan spontan, maka harus diusahakan dengan penggalangan dana yang memakai "metode lebih terhormat", misalnya dengan proposal atau door to door secara personal dan bukan dengan mengganggu di jalan raya. Memang metode ini sulit dilakukan, di samping membutuhkan tenaga, pikiran, dan waktu, juga sering dikotori oleh oknum yang memiliki kepanitiaan yang fiktif.

Ketiga, panitia atau yayasan melakukan penggalangan dana dengan sistem periodik atau donatur. Sekali lagi, matode ini tidak akan lancar seperti metode mencari di jalan, akan tetapi ia merupkan cara yang lebih terhormat untuk dilakukan karena sifatnya yang lebih terstruktur dan administratif. Kiranya metode ini harus ditunjang dengan pepatah Arab yang mengatakan bahwa:

$$
\text { الحق بلا نظام يغالبه الباطل بالنظام }
$$

Artinya: "Tindakan atau usaha yang benar yang tidak dimanaj secara tertib akan dikalahkan oleh tindakan atau usaha yang batil yang dimanaj secara tertib"

Keempat, sebagai komunitas yang merupakan mayoritas di Indonesia, umat Muslim harus bersama-sama menempatkan citra dan jati diri serta martabatnya untuk dijaga dan dipertahankan. Dengan demikian, tidak akan ada opini bahwa umat Muslim hanya menang pada tataran kuantitas tapi kalah pada tataran kualitas. Boleh jadi, secara individual masyarakat pelaku-pencari dana untuk pembangunan masjid di jalan raya yang dengan susah payah mencari dana tidak merasakan dirinya sudah terinjak-injak dengan perilakunya sendiri, akan tetapi image dan sinisme golongan lain bukan tidak mungkin untuk "menggeneralisasikan" perbuatan itu secara tidak proporsional. Hal ini karena bukan hanya mengganggu 
jalan, akan tetapi bisa saja mereka membuat stigmatisasi yang kurang menguntungkan bagi jati diri umat Muslim seluruhnya.

\section{Penutup}

Sebenarnya motivasi munculnya kegiatan pencarian dana di jalan raya adalah karena minimnya sumber daya manusia pelakupencari dana sehingga tidak mampu melakukan aktivitas yang lebih profesional dan Islami. Mereka menganggap jalan sebagai satusatunya aset yang efektif dan edisien untuk menggalang dana. Di samping itu, ada berbagai faktor yang juga turut mendorong dilakukannya aktivitas tersebut, yaitu letak geografis, sosial-budaya, ekonomi, dan motivasi vertikal (pahala). Padahal dari dimensi hukum Islam, kegiatan ini banyak menuai permasalahan, misalnya mendatangkan unsur madlarah, mengarah pada aktivitas memintaminta, dapat merendahkan martabat Islam, adanya prosentase, dan pembangunannya tidak mengarah pada unsur dlarûrah. Oleh karenanya, berdasarkan semua 'illah yang ada, maka hukum pencarian dana di jalan raya adalah haram li sadd al-dzarî'ah..

\section{Daftar Pustaka:}

'Âshûr, Muhammad Thâhir Ibn. Maqâshid al-Sharî'ah al-Islâmiyah. Yordania: Dâr al-Nafâis, 2001.

Al-Raysuni, Ahmad. Ijtihad antara Teks, Realitas, dan Kemaslahatan Sosial. Jakarta: Erlangga, 2002.

Bakar, Aboe. Sedjarah Masjid. Banjarmasin: Toko Buku Adil, 1955.

Bapedda Kabupaten Pamekasan. Kabupaten Pamekasan dalam Rangka Pamekasan Regency in Figures. Pemda Pamekasan, 2005.

Bâqi, Muhammad Fu'âd Abd al. al-Lu'lu' wa al-Marjân, vol I. Beirut: Maktabah al-'Ilmiyah, t.th.

Bustaman, Ahmad Kamaruzzaman. Islam Historis; Dinamika Studi Islam di Indonesia. Yokyakarta: Galang Printika, 2002.

Departemen Agama. Pedoman Pengelolaan dan Pengembangan Wakaf. Jakarta: Dirjen Bimbingan Masyarakat Islam dan Penyelenggaraan Haji, 2003.

Fâdanî, Abû Faidl Muhammad Yâsin bin 'Isâ al-. al-Fawâid al-Jannîyah, vol. I. Beirut: Dâr al-Fikr, 1997

Hâkim, Abd al-Hâmid. al-Sullam. Jakarta: Sa'adah Putra, t.th. 
Hakim, Lukman, et.al. Syariah Sosial; Menuju Revolusi Kultural. Malang: UMM Press, 2004.

Hasanî, Muhammad ibn Yûsuf al Sanusî al-. Mukammal Ikmâl al-Ikmâl bi Syarkh Shahîh Muslim, vol. I. Beirut: Dâr al-Kutub al-Ilmiyah, 1996.

Lakhmî, Ramadlân Abd al-Wadûd al-. al-Ta' lîl bi al-Mashlahah 'Ind alUshulîyin. Kairo: Dâr al-Huda, 1987

Maliki, Muhammad Alwi al-. Syariat Islam; Pergumulan Teks dan Realitas. Yokyakarta: el-SAQ Press, 2003.

Mujib, Abdul. Kaidah-kaidah Ilmu Figh; al-Qawâiid al-Fiqhiyyah. Jakarta: Kalam Mulia, 2001.

Permono, Sjechul Hadi. Dinamisasi Hukum Islam dalam Menjawab Tantangan Era Globalisasi. Surabaya: Dermak Press, 2002.

Qahaf, Mundhir. Manajemen Wakaf Produktif. Jakarta: Pustaka alKautsar Grup, 2005.

Shihab, Quraish. Membumikan Al-Qur`an. Bandung: Mizan, 1994.

Syahidin, Pemberdayaan Umat Berbasis Masjid. Bandung: Alfabeta, 2007

Syarifuddin, Amir. Ushul Figh 2. Jakarta: Logos Wacana Ilmu, 2001.

Tamara, M. Nasir dan Taher, Elza Peldi. Agama dan Dialog antar Peradaban. Jakarta: Paramadina, 1996.

Thaha, Mahmud Muhammad. Arus Balik Syarî'ah. Yokyakarta: LKiS, 2003.

Thûfî, Najm al-Dîn al-. al-Ta'yîn fî Sharh al-Arba'în. Beirut: Mu'assasah al-Rayyan, 1998.

Usman, Suparman. Hukum Islam; Asas-asas dan Pengantar Studi Hukum Islam dalam Tata Hukum Indonesia. Jakarta: Gaya Media Pratama, 2001.

Zahrah, Muhammad Abû. Ushûl al-Fiqh. Beirut: Dâr al-Fikr, 1958.

Zahro, Ahmad. Tradisi Intelektual NU. Yogyakarta: LKIS, 2004

Zuhaylî, Wahbah al-. al-Tafsîr al-Munîr fi al-aqîdah wa al-Syarî'ah wa alManhaj, vol. 17. Kairo: Dâr al-Kutub al-Mu'âshir, 1991 